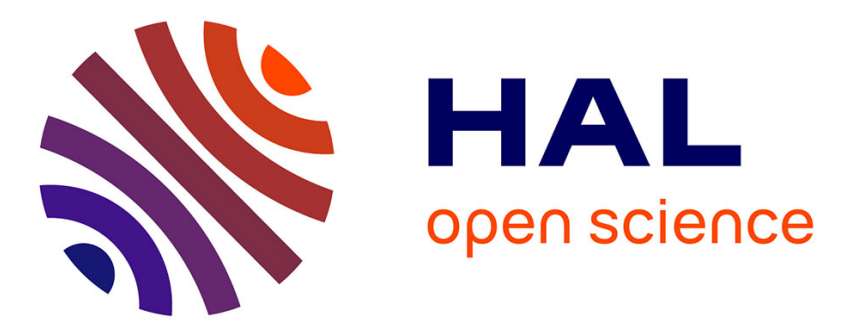

\title{
Mechanical and durability properties of concrete based on recycled coarse and fine aggregates produced from demolished concrete
}

\author{
Layachi Berredjem, Nourredine Arabi, Laurent Molez
}

\section{To cite this version:}

Layachi Berredjem, Nourredine Arabi, Laurent Molez. Mechanical and durability properties of concrete based on recycled coarse and fine aggregates produced from demolished concrete. Construction and Building Materials, 2020, 246, pp.118421. 10.1016/j.conbuildmat.2020.118421 . hal-02490854

\section{HAL Id: hal-02490854 \\ https://hal.science/hal-02490854}

Submitted on 23 Mar 2020

HAL is a multi-disciplinary open access archive for the deposit and dissemination of scientific research documents, whether they are published or not. The documents may come from teaching and research institutions in France or abroad, or from public or private research centers.
L'archive ouverte pluridisciplinaire HAL, est destinée au dépôt et à la diffusion de documents scientifiques de niveau recherche, publiés ou non, émanant des établissements d'enseignement et de recherche français ou étrangers, des laboratoires publics ou privés. 


\title{
Mechanical and durability properties of concrete based on recycled coarse and fine aggregates produced from demolished concrete
}

Layachi Berredjem ${ }^{\mathrm{a}}$, Nourredine Arabi ${ }^{\mathrm{a} *}$ nourredine.arabi@univ-annaba.dz, Laurent Molez ${ }^{\mathrm{b}}$

${ }^{a}$ Materials Geomaterials and Environment Laboratory, Badji Mokhtar-Annaba University, P.O. Box 12, 23000 Annaba, Algeria

${ }^{\text {b} C i v i l ~ a n d ~ M e c h a n i c a l ~ E n g i n e e r i n g ~ L a b o r a t o r y, ~ I N S A ~ d e ~ R e n n e s, ~} 20$ Avenue des Buttes de Coësmes, Rennes Cedex 7, France

*Corresponding author.

\begin{abstract}
Faced with aggressive environments, the durability of recycled aggregate concretes constitutes one of the most unknown aspects. The employment opportunities of recycled concrete aggregates will inevitably remain cautious due to the absence of well-established performance criteria. This paper is to investigate the influence of different granular compositions (recycled coarse and fine aggregate) on the mechanical characteristics and durability of concrete. Five series of concrete mixes, manufactured with various granular combinations (natural/recycled), were studied The formulation of the reference concrete was based on a constant quantity of $400 \mathrm{~kg} / \mathrm{m}^{3}$ of cement and a constant workability of fresh concrete securing S2 class of flowability and C25/30 concrete class, according to European standards. The experimental program consisted of comparing the long-term mechanical strength of concrete conserved in different types of water baths: fresh tap water sourced directly from the supply network, deionized water, and salt water. Also, the durability indicators were observed, such as capillary water absorption, porosity accessible to water, helium gas permeability, and an ammonium nitrate leaching test.The obtained results have highlighted the superiority of concrete composed of natural aggregate over concrete incorporating recycled aggregate for mechanical behaviour, case-observed with three types of water used as a conservation bath. The replacement of natural aggregate by recycled aggregate does not provide any substantial
\end{abstract}


improvement in terms of durability. The use of recycled sand in concrete increases its porosity and vulnerability to an aggressive environment.

Abbreviations: NA, Natural aggregates; CLS, Crushed limestone sand; RFA, Recycled fine aggregate; NCA, Natural coarse aggregate; RCA, Recycled concrete aggregate; RAC, Recycled aggregate concrete; SSD, Saturated-surface-dry; $\mathrm{NH}_{4} \mathrm{NO}_{3}$, ammonium nitrate solution

Keywords: Concrete; Recycled aggregates; Mechanical strength; Leaching; Durability

\section{Introduction}

Currently, the most widely used building material in the world is concrete [1]. Although it is strong and durable, it still generates solid wastes [2]. Moreover, NA constitutes approximately $70-80 \%$ of its total volume [3]. Therefore, it is imperative to reduce the amount of natural resources consumed and to recover its solid wastes. Various researchers have been interested in this area, where the environmental protection has become a major challenge, particularly in the use of RCAs in manufacturing concrete [4-6]. RCAs present obvious environmental benefits, but they also have similar properties to NAs in the concrete mix.

The main difference between natural and recycled aggregates is the presence of mortar attached to the surface of RCAs, which strongly affects quality, especially when they are reused for making new concrete [7].

In Algeria, the excessive use of NA is observed even for the manufacturing of low quality concrete [8,9]. With regard to, the ban on extracting alluvial materials, the depletion of the NA supply, and the difficulties of setting up new quarries, the search for new sources of aggregates critical. However, the irregularity of intrinsic characteristics, low mechanical and physical properties of RAC, and the absence of standards in force, hinder their popularization as basic materials in concrete formulation. In RAC, as in ordinary concrete, chemical attacks mainly concern the cement paste, thus presenting the same chemical reactions with the same mechanisms of aggression. However, these aggressions are all the more severe when the concrete is porous and contains free water [10].

The durability of a structure is partly correlated to the resistance of the constituent porous materials to the seepage of aggressive agents. If porosity is considered the main parameter of this resistance, two other physical quantities are important: permeability and hydric diffusivity. These are characterized by the capacity of concretes to transport a fluid (in liquid and/or vapor phases). These two parameters are considered to be the most important durability indicators. They strongly depend on the porous network, its connectivity, and the water content of the material [11].

RCAs are characterized by lower densities and higher water absorption capacities, and have lower mechanical strength than NAs [12-14]. The high porosity of RCAs is the main cause of this. The conjunction of all these factors directly effects on the basic properties of concrete: workability, mechanical resistance, and durability $[3,15]$. 
Several studies have concluded that the replacement of NA by RCA requires an increase of water/cement ratio to overcome the flow difficulties of fresh concrete [3,6,16-18]. However, as reported by Wirquin et al. [19], Chaise [20] and Olivier [21], the transport properties largely determine the durability of concrete. The absorption of water by capillarity is an undeniable tool in performance-based approaches to understand concrete durability. The capillary pores, mostly the larger ones, strongly influence the transport properties of concrete, especially when they are interconnected. To decrease the capillary porosity and its interconnection, it is necessary to reduce the water-cement ratio [21]. The capillary suction will increase the ratio, which makes concretes based on RCA more vulnerable to various aggressions.

A recent study reported by Thomas et al. [22] concludes that the durability of RAC decreases when exposed to aggressive conditions, such as permeability. They also add that the quality of the cement paste of RAC can be a bulwark against the influence of the environment. The authors of this study concluded that the use of RCAs causes the loss of mechanical properties and durability and these are lower in the marine environment than those in a standard curing environment (i.e., humidity chamber at $20^{\circ} \mathrm{C}$ and $95 \%$ humidity).

Few studies in the literature have focused on the study of durability indicators for concretes formulated with a total integration of RCAs (fine and coarse) [23]; and the obtained results are not comparable due to the heterogeneity of RCAs. Especially as the adhered mortar content in RCAs constitutes a major impact on the strength and durability of RAC. Thus, the employment opportunities of recycled concrete aggregates will inevitably depend on well-established performance criteria. In the end, the conducted investigation serves as a substantial contribution where durability studies of concrete based on RCA are, therefore, an essential step to assign them an area of use.

The main objective of this research is to compare the long-term (one-year) mechanical strengths of concrete composed of NA and concrete incorporating RCA conserved in different types of water baths: tap-water, demineralized water, and salt water. In a second step, the durability indicators such as capillary water absorption, porosity accessible to water, helium gas permeability, and ammonium nitrate leaching, were observed.

\section{Details of the experiment}

\subsection{Materials used}

\subsubsection{Cement}

The cement used in this study is a CEM-II 42.5 type, according to the Algerian Standard NA 442-2003 [24], produced by cement plants in Algeria with an average of a 28-day compressive strength of $42 \mathrm{MPa}$. The main chemical, Bogue composition, and physical and mechanical characteristics of the cement are given by the manufacturer, present in Table 1. 
Table 1

Characteristics and composition of the used cement.

\begin{tabular}{|c|c|c|c|c|c|c|c|c|c|c|}
\hline $\mathrm{CaO}$ & $\mathrm{Al}_{2} \mathrm{O}_{3}$ & $\mathrm{SiO}_{2}$ & $\mathrm{~F}_{2} \mathrm{O}_{3}$ & MgO & $\mathrm{Na}_{2} \mathrm{O}$ & $\mathrm{SO}_{3}$ & $\mathrm{~K}_{2} \mathrm{O}$ & $\mathrm{Cl}^{-}$ & Loss on ignition & Free $\mathrm{CaO}$ \\
\hline 60.40 & 5.17 & 22.00 & 3.00 & 1.50 & 0.13 & 2.50 & 0.45 & 0.01 & 3.83 & 1.01 \\
\hline
\end{tabular}

\begin{tabular}{|l|l|l|l|l|}
\hline \multicolumn{2}{|l|}{ Bogue composition (\%) } & (\%) & Gypsum \\
\hline $\mathrm{C}_{3} \mathrm{~S}$ & $\mathrm{C}_{2} \mathrm{~S}$ & $\mathrm{C}_{3} \mathrm{~A}$ & $\mathrm{C}_{4} \mathrm{AF}$ & 5.0 \\
\hline 59.3 & 19.1 & 8.3 & 7.2 & \\
\hline
\end{tabular}

\begin{tabular}{|l|l|}
\hline Physical and mechanical properties & 3.13 \\
\hline Specific gravity & 3280 \\
\hline Blaine specific surface area $\left(\mathrm{cm}^{2} / \mathrm{g}\right)$ & 155 \\
\hline Initial set (min) & 5 \\
\hline Final set (hours) & 27 \\
\hline Consistency of cement paste (\%) & 42.5 \\
\hline Strength class (MPa) & 42 \\
\hline Compressive strength at 28-day (MPa) & 5 \\
\hline
\end{tabular}

Table 1 Characteristics and composition of the used cement

\subsubsection{Aggregates}

The aggregates used in this study are NAs and RCAs. NAs are crushed limestone obtained from a local quarry, divided into three size fractions $(0 / 3.15,3 / 8$, and $8 / 16 \mathrm{~mm})$. RCAs are obtained from the demolition structural precast concrete elements of insalubrious buildings. The properties of the old concrete are unknown. The large pieces of concrete were transported to the laboratory, then were crushed and graded. The size fractions used for RCAs were $0 / 3.15,3 / 8$, and 8/16 mm. The particle size distributions of NA and RCA are shown in Fig. 1 and their chemical compositions and physical properties in Tables 2 and 3, respectively. The chemical compositions of these aggregates were determined through X-ray fluorescence (XRF) at INSA Rennes in France and the physical properties, conducted according to the EN 12620 European standards [25], were determined at the Civil Engineering laboratory in Badji Mokhtar or Annaba University, Algeria. 


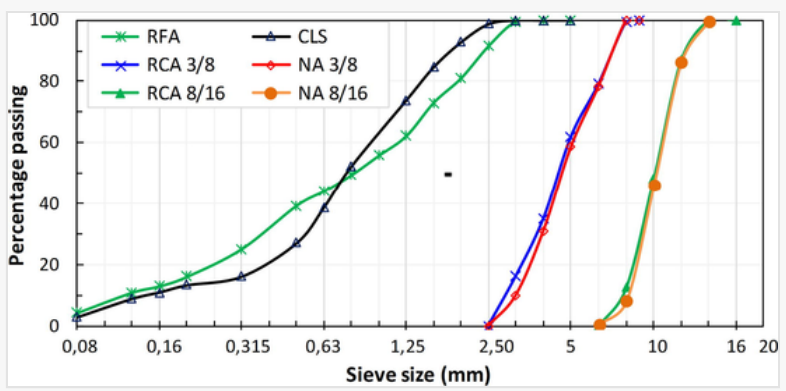

Particle size distribution of the aggregates studied.

Table 2

Chemical compositions of aggregates.

\begin{tabular}{|l|l|l|l|l|l|l|l|l|l|l|l|}
\hline Oxide weight (\%) & $\mathbf{C a O}$ & $\mathbf{A l}_{2} \mathbf{O}_{3}$ & $\mathbf{S i O}_{2}$ & $\mathbf{F}_{2} \mathbf{O}_{3}$ & $\mathbf{M g O}$ & $\mathbf{N a}_{2} \mathbf{O}$ & $\mathbf{S O}_{3}$ & $\mathbf{K}_{2} \mathbf{O}$ & $\mathbf{C l}^{-}$ & \multicolumn{2}{l}{ Loss on ignition } \\
\hline NS & 52.61 & 1.82 & 15.9 & 0.67 & - & - & 0.77 & 0.21 & - & 28.02 \\
\hline NAC & 55.51 & 1.1 & - & 0.6 & 0.2 & 0.08 & - & 0.01 & - & 42.5 \\
\hline RS & 38.25 & 2.61 & 26.52 & 1.22 & - & - & 1.96 & 0.22 & - & 29.09 \\
\hline RAC & 44.63 & 4.96 & 26.34 & 2.36 & 1.01 & 0.6 & 0.06 & 1.2 & 0.03 & 18.6 \\
\hline
\end{tabular}

Physical properties of aggregates.

\begin{tabular}{|c|c|c|c|c|c|c|}
\hline \multirow{3}{*}{ Type } & \multirow{3}{*}{$\begin{array}{l}\text { Sand } \\
\text { CLS }\end{array}$} & \multirow{3}{*}{ RFA } & \multicolumn{3}{|l|}{ Coarse } & \multirow[b]{3}{*}{$8 / 16 \mathrm{~mm}$} \\
\hline & & & NCA & & RCA & \\
\hline & & & $3 / 8 \mathrm{~mm}$ & $8 / 16 \mathrm{~mm}$ & $3 / 8 \mathrm{~mm}$ & \\
\hline Apparent volumetric mass $\left(\mathrm{kg} / \mathrm{m}^{3}\right)$ & 1410 & 1240 & 1540 & 1490 & 1140 & 1090 \\
\hline
\end{tabular}




\begin{tabular}{|l|l|l|l|l|l|l|}
\hline Absolute volumetric mass $\left(\mathrm{kg} / \mathrm{m}^{3}\right)$ & 2590 & 2510 & 2630 & 2740 & 2520 & 2560 \\
\hline Fineness modulus & 2.38 & 2.78 & & & \\
\hline Sand equivalent (\%) & 92.52 & 87.52 & & & \\
\hline Aggregate cleanness (\%) & & & 3.5 & & 7.2 & \\
\hline Water content (\%) & 1.12 & 2.93 & 0.31 & 0.18 & 4.57 & 1.93 \\
\hline Water absorption after 24 $\mathrm{h}(\%):$ & 2.19 & 12.81 & 0.95 & 0.64 & 6.83 & 5.37 \\
\hline Los Angeles testing (\%) & & & 29.47 & & 39.52 & \\
\hline Micro-Deval testing (\%) & & & 22.31 & & 38.60 & \\
\hline
\end{tabular}

\subsection{Concrete mixtures}

The Dreux-Gorisse mix design method was used for concrete [26]. All concrete mixes were prepared with a constant quantity of $400 \mathrm{~kg} / \mathrm{m}^{3}$ of cement, a constant workability of fresh concrete securing S2 class of flowability, and C25/30 concrete class of compressive strength at the age of 28-days for a XA2 exposure class, according to the European standard EN 206-1 [27].

Five different concrete mixes were designed for this study to investigate the effect of incorporating different granular combinations of aggregates (natural/recycled) on the mechanical and durability performances of concrete. Details of mixture proportions of the investigated concretes are presented in Table 4 . The notations used are as follows:

- B1: Concrete made with natural aggregates (coarse and fine);

- B2: Concrete made with fine RCA (RFA) and natural coarse aggregates (NCA);

- B3: Concrete made with natural fine aggregates (CLS) and coarse RCA;

- B4: Concrete made with a full replacement of NAs by RCAs (coarse and fine);

- B5: Concrete made with natural fine aggregates (CLS) and 75\% NCA + 25\% coarse RCA.

\section{Table 4}

Mix proportions of concretes.

\section{Proportions $\left(\mathrm{kg} / \mathrm{m}^{3}\right)$}

B1

B2

B3

B4

B5 


\begin{tabular}{|c|c|c|c|c|c|c|}
\hline Cement & 400 & 400 & 400 & 400 & 400 & \\
\hline CLS & 578 & & 578 & & 578 & \\
\hline RFA & & 571 & & 571 & & \\
\hline NCA $3 / 8 \mathrm{~mm}$ & 185 & 168 & & & 139 & \\
\hline NCA $8 / 16$ mm & 928 & 928 & & & 696 & \\
\hline $\mathrm{RCA} 3 / 8 \mathrm{~mm}$ & & & 176 & 160 & 44 & \\
\hline RCA $8 / 16 \mathrm{~mm}$ & & & 874 & 874 & 219 & \\
\hline \multirow[t]{3}{*}{ Mixing water (in liters) } & Effective water & 187 & 187 & 187 & 194 & 187 \\
\hline & Added water & 0 & 51 & 39 & 71 & 21 \\
\hline & Total added water & 187 & 238 & 226 & 265 & 208 \\
\hline Water/Cement ratio (W/C) & 0.47 & 0.59 & 0.56 & 0.66 & 0.52 & \\
\hline Slump (cm) & 6.50 & 7.50 & 7.00 & 7.50 & 6.50 & \\
\hline \multirow[t]{2}{*}{ Fresh density $\left(\mathrm{kg} / \mathrm{m}^{3}\right)$} & Real & 2321 & 2296 & 2277 & 2207 & 2300 \\
\hline & Calculated & 2278 & 2305 & 2254 & 2270 & 2284 \\
\hline
\end{tabular}

Table 4 Mix proportions of concretes

Generally, RCAs have higher water absorption than NAs, as presented in Table 3. Therefore, RCAs were used in saturated-surface-dry (SSD) condition, while natural aggregates were maintained in dry state for all concrete mixes.

All concrete specimens were unmoulded $24 \mathrm{~h}$ after casting and then cured during the 28 days into water at $20{ }^{\circ} \mathrm{C}$ (tap water). Following this, the specimens were conserved until 360 days into three different types of water baths: fresh mains water sourced directly from supply network, deionized water, and saltwater with a concentration of $5 \mathrm{Mol} / \mathrm{L}$. For each concrete mixture, $100 \mathrm{~mm}$ cubes, $110 \times 200 \mathrm{~mm}$ cylinders, and $70 \times 70 \times 280 \mathrm{~mm}$ prisms were cast. The cubes were used to determine the compressive strength, the cylinders to evaluate the tensile splitting strength, and prisms and cylinders were prepared to measure the durability indicators. The durability indicators included the following: capillary water absorption, porosity accessible to water, helium gas permeability, and ammonium nitrate leaching test.

The compressive and splitting tensile strengths were measured at the ages 28, 90, 180, 270, and 360 days. Further, the specimens intended to evaluate durability indicators were cured in a water bath at $(22 \pm 2){ }^{\circ} \mathrm{C}$ for 90 days.

\subsection{Durability indicators}

This study evaluated the four following durability indicators: capillary water absorption, porosity accessible to water, helium gas permeability, and ammonium nitrate leaching test. 
The test for capillary water absorption was conducted according to the EN 480-5 [28]. It was performed on a cylinder $110 \mathrm{~mm}$ in diameter and $50 \mathrm{~mm}$ thick. First, the specimens were dried at a temperature of $105{ }^{\circ} \mathrm{C}$ in a dryer until a mass constant was obtained. The samples were then submerged in water at a constant level of about $5 \mathrm{~mm}$ above the bottom surface of the specimen. With a measurement accuracy to $0.1 \mathrm{~g}$, the specimens were weighed at different time periods $\left(t_{i}\right)$ initially and then 15, 30, 60, 120, 240, 360, 480, and 1440 min after their first contact with water.

The water accessible porosity test was conducted on cylindrical specimens $110 \mathrm{~mm}$ in diameter and $50 \mathrm{~mm}$ long. The test protocol was consistent with the NF EN 18-459 [29]. This method required saturating the materials with water and then drying them off. The samples were first kept in a vacuum bell for $24 \mathrm{~h}$ and then they were immersed in water and maintained in a vacuum for $48 \mathrm{~h}$ (Fig. 2). Using a hydrostatic weighing device, the samples' volumes were measured by weighing them in air and in water. For the dry mass, the samples were dried at $105 \pm 5^{\circ} \mathrm{C}$ until a constant weight was obtained. The porosity accessible to water, $p$ (\%), was calculated by referring to the formula in the ASTM C 642 standard [30].

\section{Fig. 2}

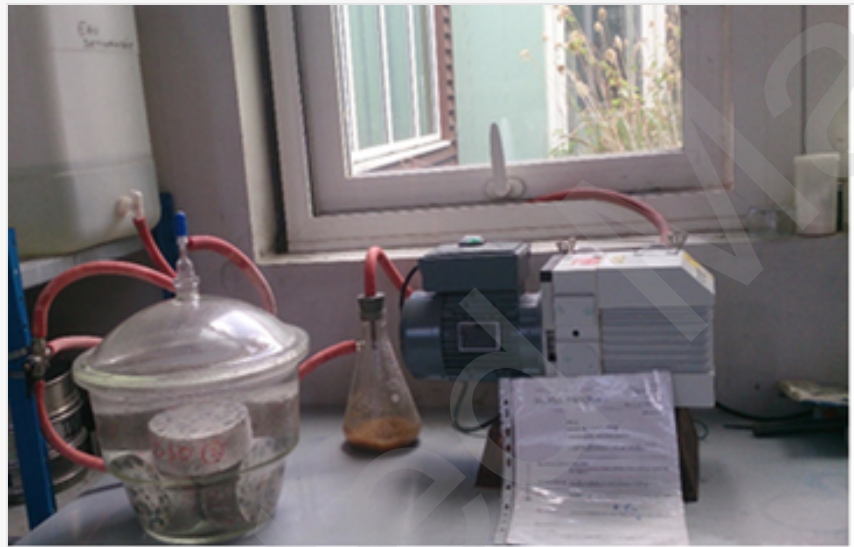

Device of saturating samples

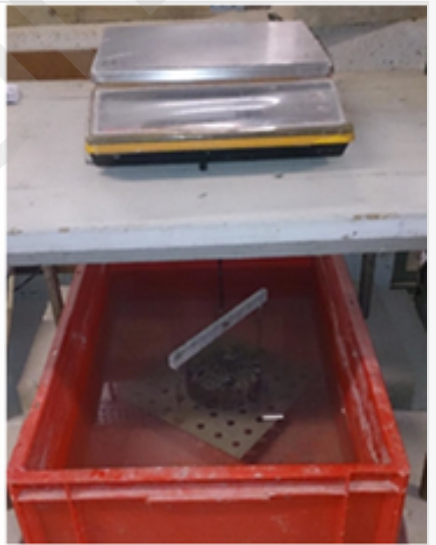

Hydrostatic weighing device

Device of capillary water absorption test.

The gas permeability of concrete was tested using the method developed by Cembureau [31]. The devices used were a helium bottle from $20 \mathrm{MPa}$ and a permeability cell that emitted a percolation gas up to 2 bars of absolute pressure and a containment gas of 5 bars absolute pressure. A cylindrical sample of $110 \mathrm{~mm}$ diameter and $50 \mathrm{~mm}$ thickness was placed in the permeability cell, enabling the injection of the percolation gas and guaranteeing the lateral sealing of the sample by the intermediary of a rubber membrane wrapped by containment gas. Fig. 3 shows the used device for gas permeability test. 


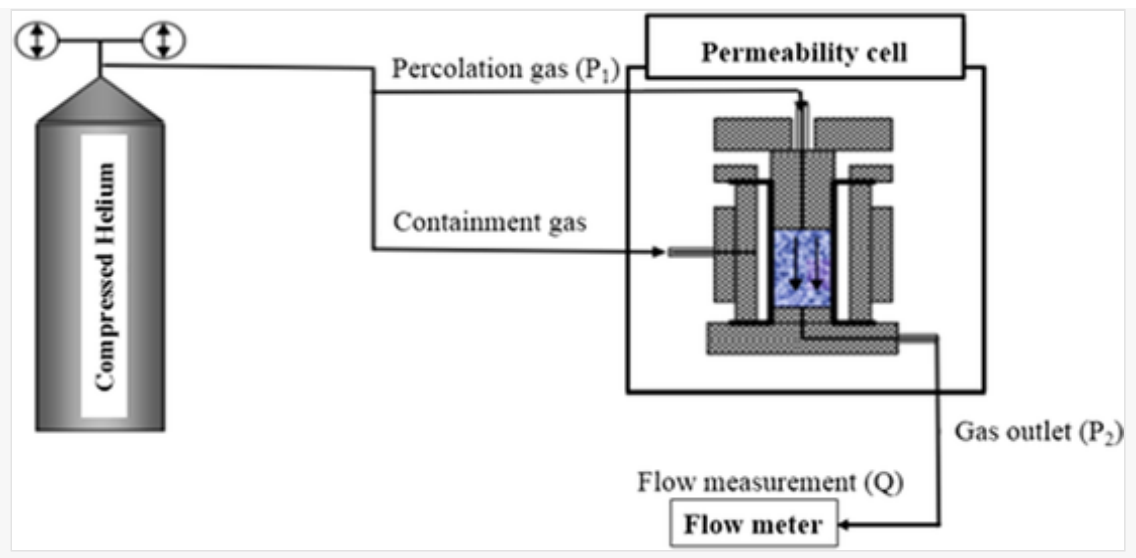

Device of gas permeability test [32].

Cored specimens, $\varnothing 40, \mathrm{~h}=60 \pm 01 \mathrm{~mm}$, were used as test specimens for the ammonium nitrate leaching test. After 90 days' curing of specimens in water at $20{ }^{\circ} \mathrm{C}$ (tap water), the specimens were immersed for 14 and 28 days in two different baths of ammonium nitrate solution $\left(\mathrm{NH}_{4} \mathrm{NO}_{3}\right)$ at concentrations of $1.5 \mathrm{Mol} / \mathrm{L}$ and $6 \mathrm{Mol} / \mathrm{L}$. Fig. 4 shows the cored specimens which were completely immersed in $\mathrm{NH}_{4} \mathrm{NO}_{3}$ at concentration $6 \mathrm{Mol} / \mathrm{L}$. The specimens were placed on a bed of plastic ball so that the underside was leached by $\mathrm{NH}_{4} \mathrm{NO}_{3}$. Further, the environment was permanently shaken to favour diffusion.

\section{Fig. 4}

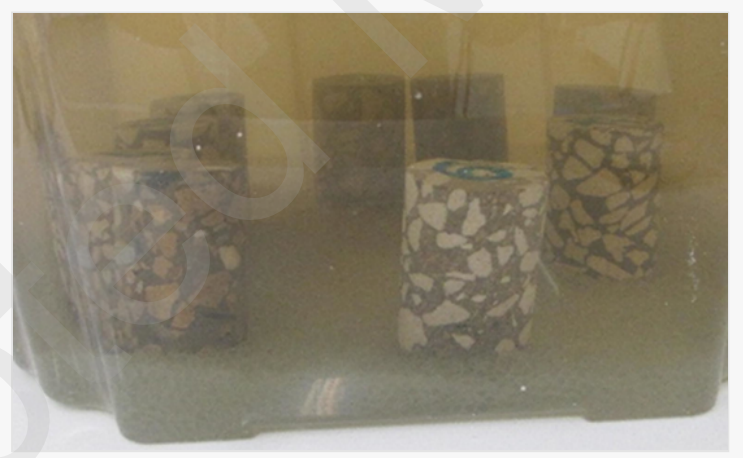

Specimens of concrete immersed in $\mathrm{NH}_{4} \mathrm{NO}_{3}$ at concentration $6 \mathrm{Mol} / \mathrm{L}$.

\section{Results and discussion}

\subsection{Fresh state properties}

The obtained results from the tests carried out on slump of fresh concrete and fresh density for concrete mixes are presented in Table 4. The slump increased for the concrete mixes prepared with RCAs. These were used in the SSD condition, which provided a higher initial free water content in RAC mixes. However, the slump results are consistent with the consistency specified in the S2 class of flowability $(5-9 \mathrm{~cm})$. Moreover, for concretes made with RCA and fine RCA, it was necessary to vary the water content, due to their absorption, to obtain the required consistency that guarantees the S2 class of flowability. Additionally, the concrete mixes 
containing fine RCA required more added water than the others. The fine RCA is distinguished by a high porosity, a fine fraction $(<0.63 \mathrm{~mm})$ and a high-water absorption.

The RAC mixes present low fresh densities in comparison to reference concrete (B1), which is mainly due to the intrinsic characteristics of RCAs. Notably, several studies confirm the same $[9,14,33,34]$. Their results have shown a convergence regarding the effect of incorporating RCA on the fresh density of RAC. As reported by Cachim [33], which observed a clear and obvious reduction of density when recycled aggregates were used. It was noted a density loss of about 5\% when $100 \%$ coarse RCAs are incorporated in place of NAs. In another study also conducted by Katz [34], which produced completely recycled mixes and observed a decrease of fresh density from around $2400 \mathrm{~kg} / \mathrm{m}^{3}$ to $2150 \mathrm{~kg} / \mathrm{m}^{3}$.

\subsection{Hardened state properties}

\subsubsection{Compressive strength}

Figs. 5-7 illustrate compressive strength of concrete mixes cured in fresh mains water, deionized water, and saltwater, respectively. It can be observed that all concrete samples at the age of 28 days achieved the C25/30 concrete class of compressive strength. The results show an evidently increasing trend for all the curing durations. For the three conservation baths, it was seen that the concrete mixes (B2 and B4) containing fine RCA had lower compressive strengths as compared to other mixes. This demonstrates that the use of fine RCA in concrete would yield a deleterious effect over the hardened properties due to the poor quality of the fine aggregates employed and the increase of mixing water. It is known that the high $\mathrm{W} / \mathrm{C}$ ratio produces lower strength values. These results are coherent with those obtained by Sérifou et al. [35], who had concluded that the use of coarse and fine RCA in concrete lowers the compressive strength. As shown in Figs. 5-7, the superiority is guaranteed by the concrete mixes (B1 and B5), which are composed only of natural aggregates for the first and $75 \% \mathrm{NCA}+25 \%$ coarse RCA for the second. It should also be noted that the specimens removed from saltwater after 12 months of immersion did not in any case show visible superficial defects. In addition, no concrete degradation was noticed as a result of a probable leaching with deionized water.

\section{Fig. 5}

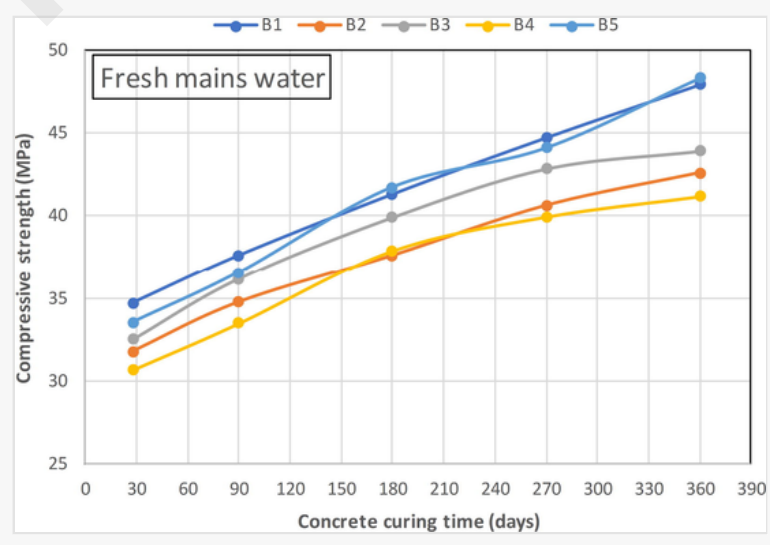

Compressive strength of concretes conserved in fresh mains water. 
For curing in fresh mains water (Fig. 5), it was found that, in general, the kinetics of hardening concrete for mixes composed of RCA does not differ much from that of conventional concrete, principally in the first three months of curing. After this duration, a disparity of the kinetics of hardening concrete seems to appear between the mixes composed of NAs (B1 and B5) and RCA (B2, B3, and B4). This also applies to the curing of concrete in deionized water (Fig. 6) and saltwater (Fig. 7). This can be explained by the quality of interfacial transition zone (ITZ) microstructure in compressive strength evolution of concrete. As related by Poon et al. [36], who demonstrated that the ITZ microstructure significantly influences the properties of RAC. The RCA-based concrete has an ITZ microstructure different than that of the concrete based on NAs. The high porosity and water absorption capacity of RCAs make the ITZ even poorer. It was also found that the nature of aggregates strongly influences the ITZ quality [37]. In the present study, NAs used in the mixes (B1 and B5) are of limestone origin. Limestone aggregates have a stronger transition zone and a lower permeability due to chemical reactions that occur with the cement paste over time. This could be one of the most likely reasons for the improvement in compressive strength after the first three months of curing. Further, the chemical reaction with limestone aggregates and cement paste did not develop quickly enough. On the contrary, while preparing RAC with new cement paste cracks were concentrated within the ITZs between aggregates and old mortar, which presents the "weakest link" of the microstructure of RAC. On the other hand, it must be noted that the RAC is different from concrete based on NA. It possesses only one ITZ which is present between the mortar matrix and original aggregate, while the RAC has two ITZs: one formed between the new mortar matrix and the RCA, and the second "old ITZ" that already exists between the old mortar attached and the RCA. Therefore, the old mortar of RCA composed of porosity and many cracks, also becomes the "weakest link" in concrete based on RCA [38]. As illustrated in Fig. 8, the crack initiated at ITZ. The figure shows a coarse RCA composed of old paste (spectrum 1866), old ITZ (spectrum 1865), and coarse NA of limestone origin (spectrum 1867) and the EDS spectrums for these crystallised phases are show in Fig. 8a-c, respectively. The profile presented in Fig. 9 was obtained from the SEM image and microanalysis of coarse RCA of concrete mix B3 at the age of 90 days. We also noticed that the crack developed at ITZ at about $25 \mu \mathrm{m}$ from the interface with the coarse NA. In such a case, the ITZ represents the bridge between the two constituents: the old paste and the coarse NA. If this bridge (ITZ) is poor in quality, it becomes the spot that initiates damage.

\section{Fig. 6}

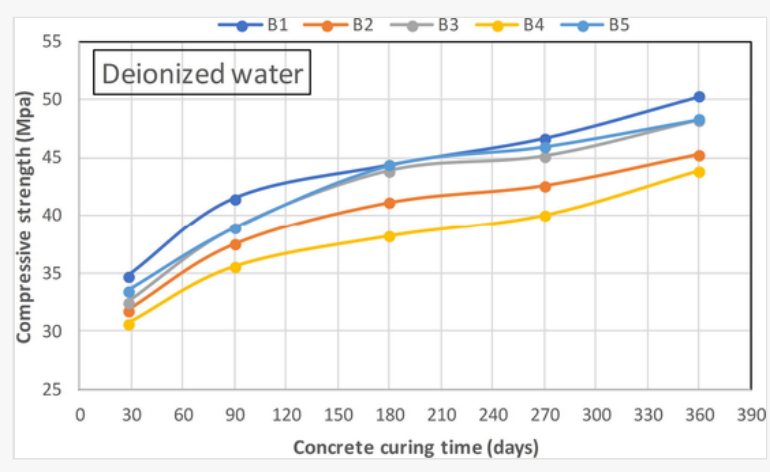

Compressive strength of concretes conserved in deionized water. 
Fig. 7

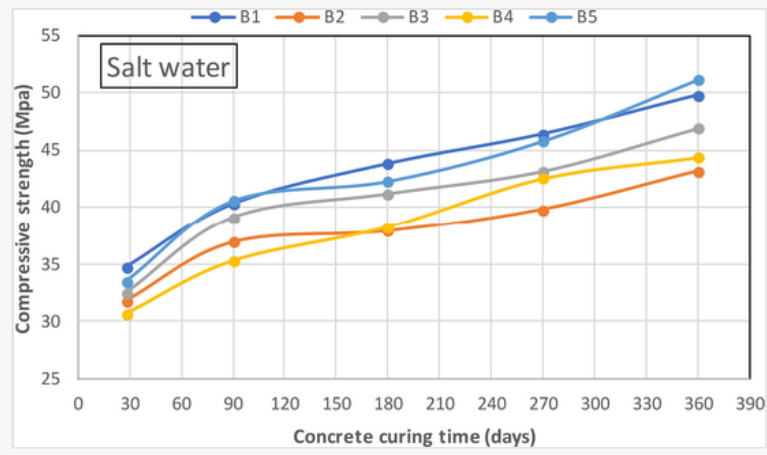

Compressive strength of concretes conserved in salt water.

Fig. 8

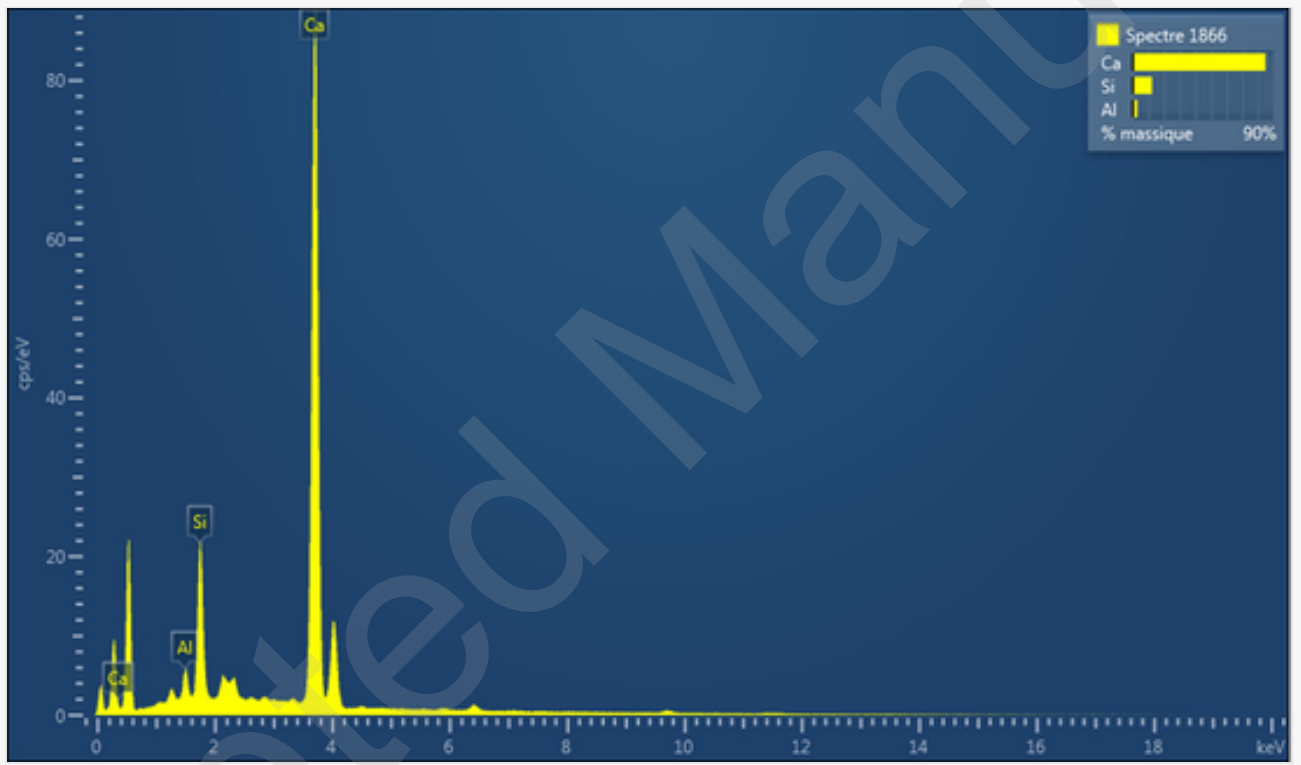



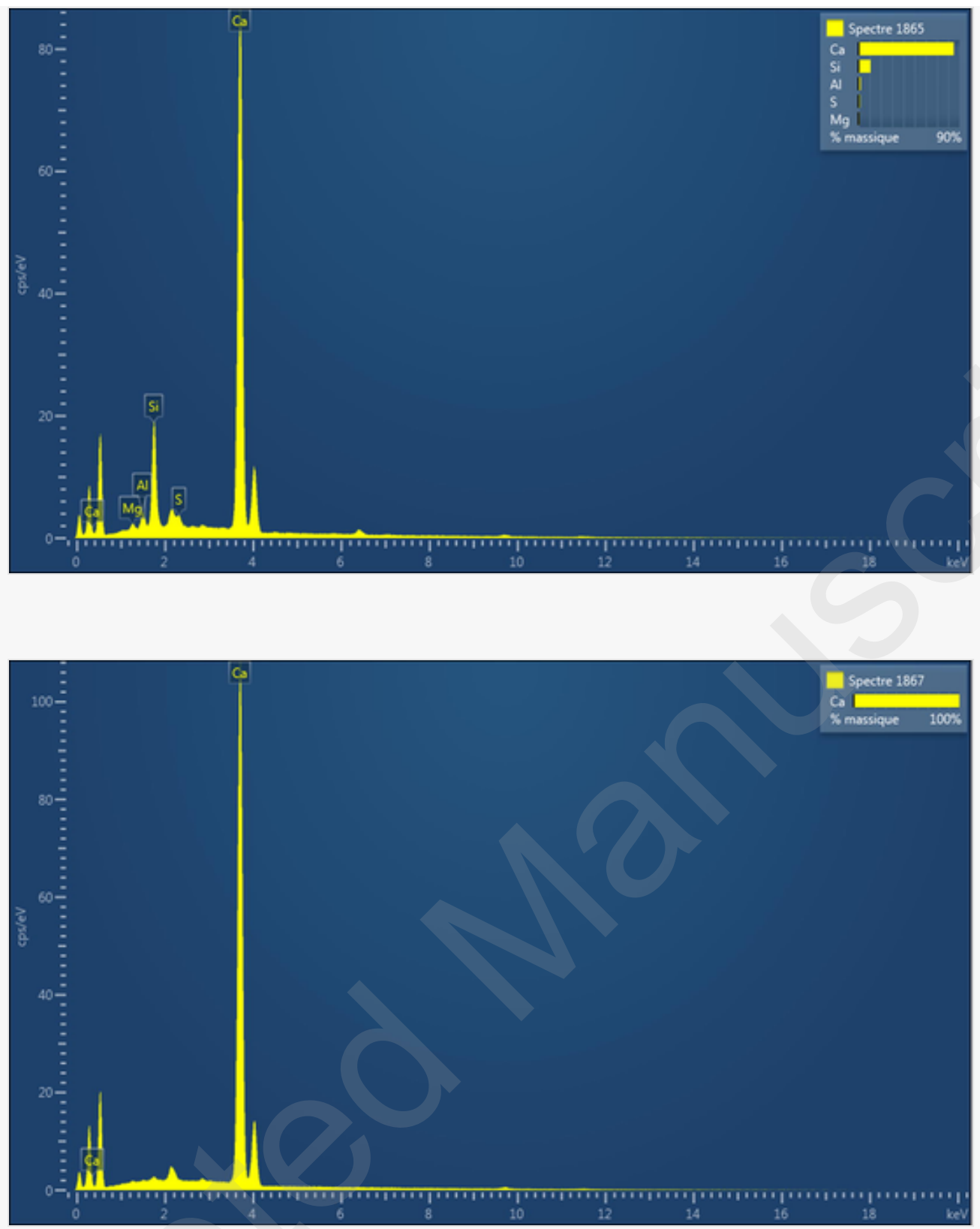

SEM image of the interfaces between limestone origin, old ITZ and old cement paste in concrete B3 at 28 days Fig. 8a. EDX pattern of the old paste (spectrum 1866) Fig. 8b. EDX pattern of the old ITZ (spectrum 1865) Fig. 8c. EDX pattern of the limestone origin (spectrum 1867). 


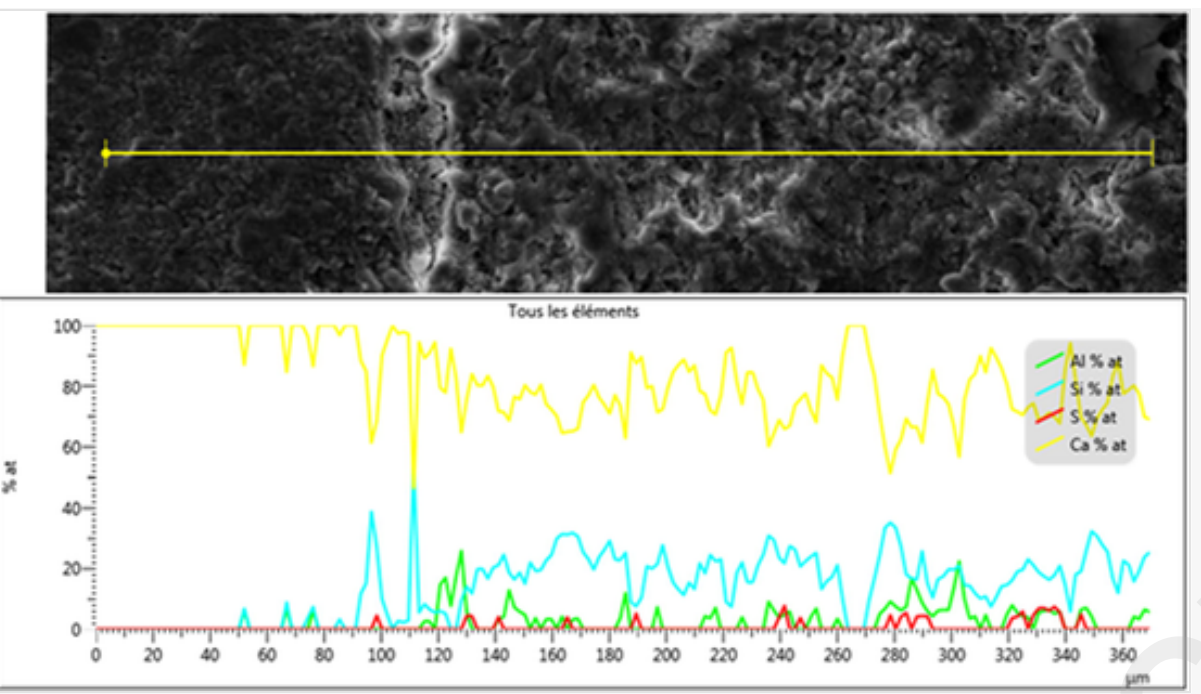

SEM and microanalysis of concrete B3 at 90 days.

\subsubsection{Tensile splitting strength}

Fig. 10(a-c) illustrates the tensile splitting strength of concretes conserved in different types of water baths. As depicted in these figures, there is a similar trend as seen in the compressive strength figures represented in Figs. 5-7. According to the European standard NF EN 206-1 for C25/30 concrete class, the obtained tensile strength values (at 28-days) for all concrete mixtures are considerably superior to the characteristic tensile strength $\left(f_{c t k}\right)$.

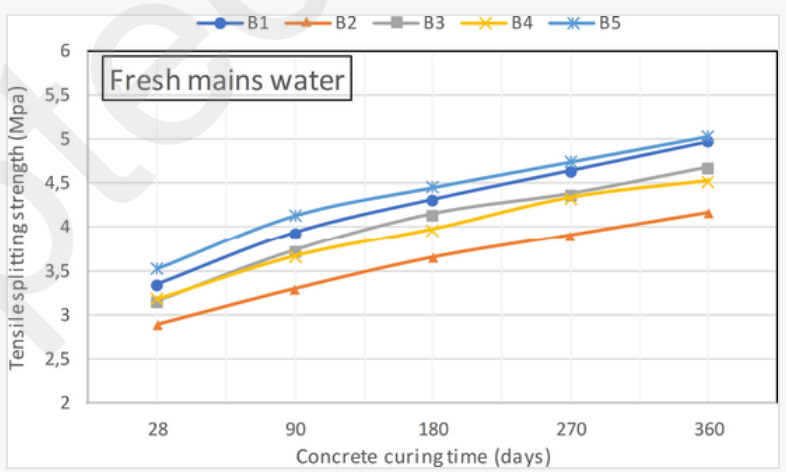



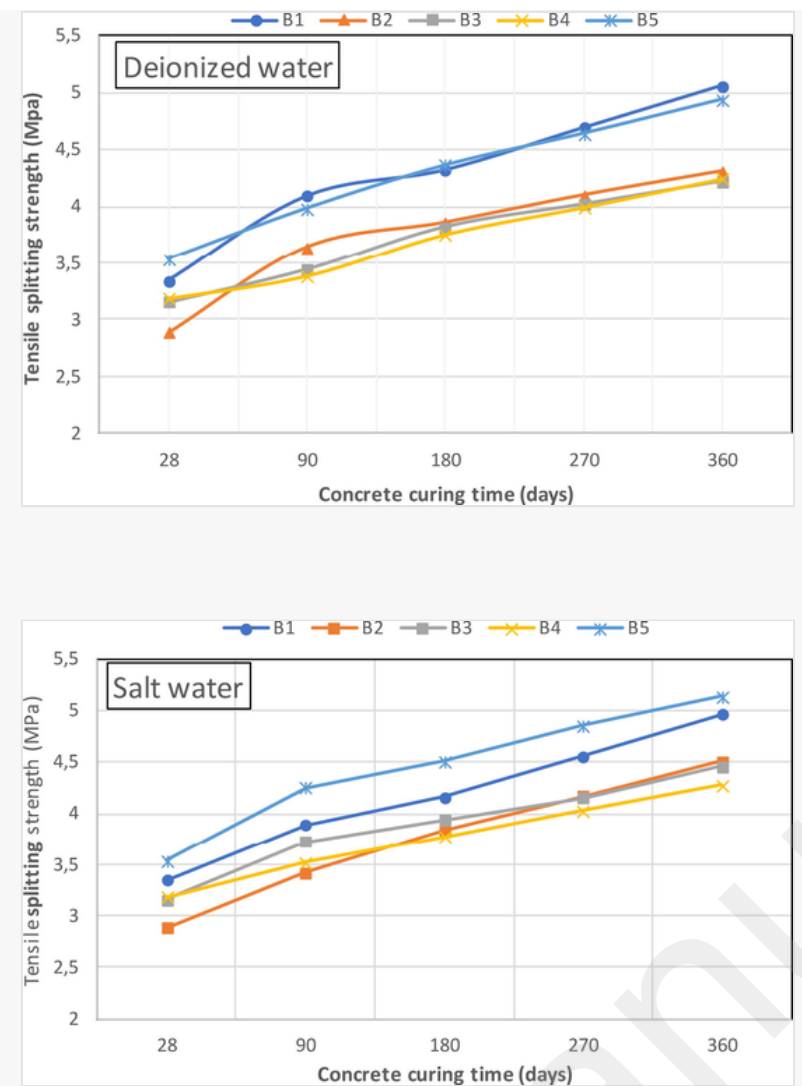

Change of tensile splitting strength of concretes conserved in different types of water baths Fig. 10a. Concrete conserved in fresh mains water Fig. 10b. Concrete conserved in deionized water Fig. 10c. Concrete conserved in salt water.

However, it is also known that the concrete produced employing RCAs does not develop a splitting tensile strength better than concrete produced by NAs [3,16]. As reported by Weerheijm [39], tensile strength is closely related to the strength of the cementitious matrix and to the adhesion (bond) of the matrix to the aggregate grains. A high water/cement (W/C) ratio may result in low matrix strength and poor ITZ and consequently reduced tensile strength of the concrete. As reported by Djerbi [40], when the RCAs used in the pre-saturation state influence the ITZ of RAC, the water contained in the pores of RCAs will migrate towards the new paste, affecting its microstructure (new ITZ). This mechanism induces additional porosity in RAC. Another explanation by Poon et al. [41] offered that, during the vibration process, the water absorbed by RCA particles tends to migrate toward the cement matrix, thus forming a region with an increased $\mathrm{W} / \mathrm{C}$, which would create a zone with a high porosity. This process can weaken the ITZ. This has also been asserted by Barra de Oliveira and Vazquez [42]: when the RCAs are used in SSD condition, the ITZ becomes ineffective and the concrete properties weaken. As reported in one of our previous papers [3], the ITZ tends to act as the "weak link in the chain" in comparison to cement paste and aggregate particles.

\subsection{Durability properties}

\subsubsection{Capillary water absorption}

Fig. 11 indicates the capillary water absorption values of different concretes tested over a period of $1440 \mathrm{~min}$. In general, the curves in this figure show similar absorption trends for all concretes. According to obtained 
results, the concrete mixes (B1 and B5) show better performance, which was also observed with the compressive strength (Figs. 5-7). The capillary water absorption of concrete mix B4 produced with a full replacement of NAs by RCAs (coarse and fine), showed much higher results than the other concretes. This was probably due to the porous network of RFA and RCA, particularly in RFA composed by old cement paste characterized by high porosity, a fact that has also been reported by other researchers $[9,18]$.

\section{Fig. 11}

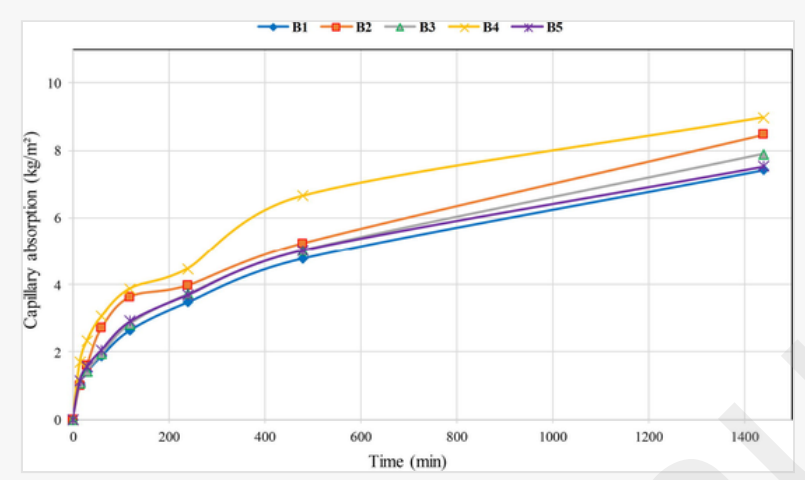

Capillarity water absorption vs time.

Importantly, the test results imply that the final value of the capillary absorption (at $1440 \mathrm{~min}$ ) depends directly on the $\mathrm{W} / \mathrm{C}$ ratio, which was employed in the concretes' manufacture [12]. This high W/C ratio, mainly for concretes composed with RCA, was necessary to maintain the same workability level as that of the reference concrete (B1). As a result, the free water not used in cement hydration but only to manufacture a workable concrete contributed to the creation of a larger capillary pore system [43].

\subsubsection{Water-accessible porosity}

The results of the water accessible porosity test are shown in Fig. 12. Similar trends are also shown for compressive strength and capillary water absorption figures. Moreover, the results show that the water accessible porosity increased for the mixes containing RCAs and increased more significantly when fine RCAs were used (concrete mixes B2 and B4). For these two concrete mixes, the test results of water accessible porosity were $42 \%$ and $64 \%$ higher than that of the reference concrete (B1), respectively. Thus, the water accessible porosity is directly related to the porosity of RCAs and the W/C ratio used, which leads to a more porous microstructure. Further, the concrete mixes that needed more water were B2 and B4 (Table 4). 


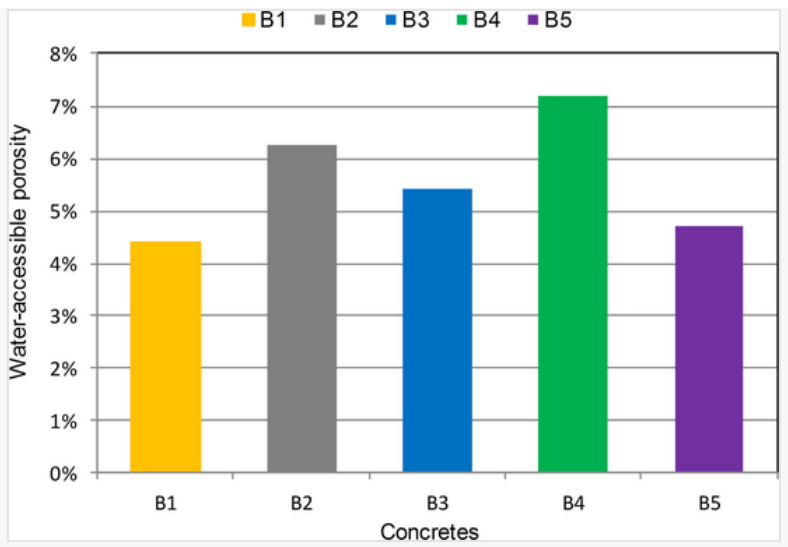

Water-accessible porosity versus concrete mixes.

\subsubsection{Gas permeability}

The Hagen-Poiseuille law was applied to calculate the apparent gas permeability [31]. This is applicable for laminar flow of a compressible fluid through a porous body under steady state conditions. Fig. 13 illustrates the variation of apparent coefficient of gas permeability " $\mathrm{K}_{\text {app}}$ ". This figure shows a perfect similarity with Fig. 12, which contains the variation of the water accessible porosity of concrete mixes. These results are in agreement with Xuan et al. [44], who show RCAs' influence on the durability of RAC.

\section{Fig. 13}

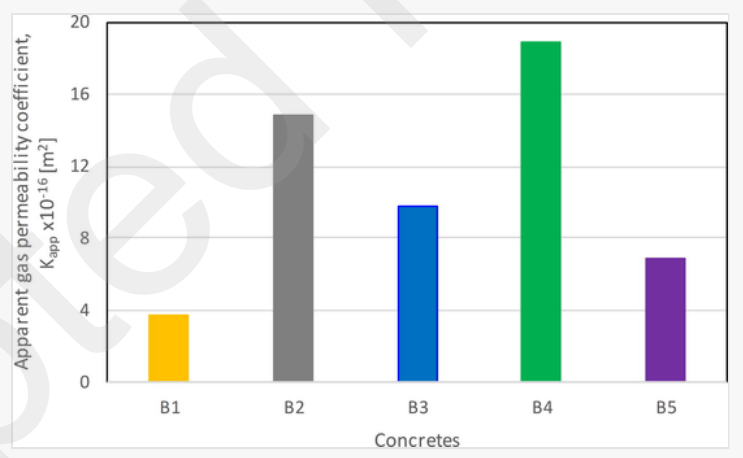

Variation in apparent gas permeability of concrete mixes.

Moreover, concretes incorporating RCAs exhibited higher gas permeability coefficients compared to the reference concrete (B1). The measured maximum increase reached $411 \%$ for mixture B4 and $300 \%$ for mixture B2. To explain this variation, it can be assumed that the interface between aggregate and mortar matrix contains pores, thus increasing the permeability. In addition, RCAs act as bridges between the pores creating interconnections, allowing the gas to flow through the mortar matrix.

The general trend is that the gas permeability has a good correlation with the water accessible porosity values of concretes manufactured (Fig. 14). This is similar to the relation between permeability and capillary water absorption (Fig. 15). Therefore, it can be concluded that the water accessible porosity value or the capillary 
water absorption of concretes tested in this study could provide an evolution trend of the apparent coefficient of gas permeability of concretes based on RCAs [44].

\section{Fig. 14}

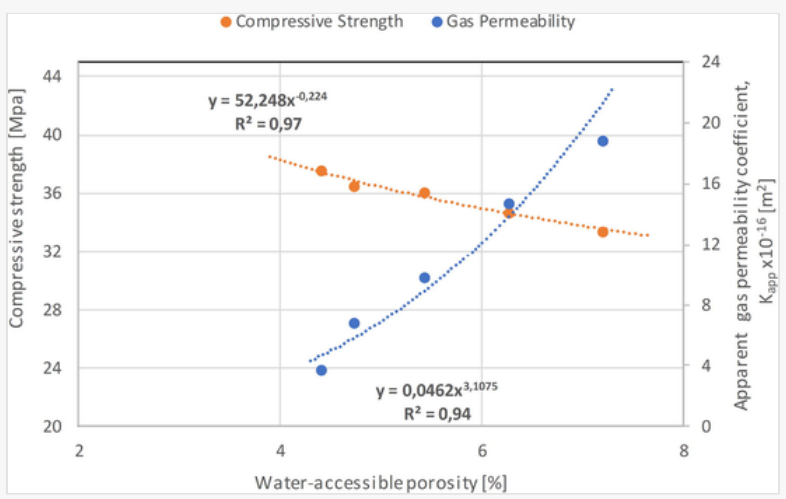

Relationship between water-accessible porosity with compressive strength and apparent gas permeability of concrete mixes.

\section{Fig. 15}

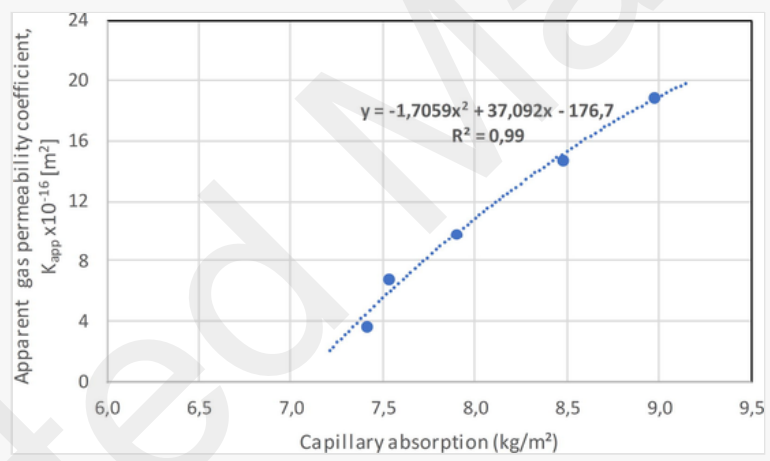

Relationship between capillary water absorption with and apparent gas permeability of concrete mixes.

In the study, it was demonstrated that the permeability is closely related to compressive strength; a higher compressive strength of concrete corresponds to concrete at lower permeability and conversely a lower resistance, with high porosity, and guarantees a more permeable concrete, as shown in Fig. 14. The B2 and B4 concrete mixes (Fig. 5) having the lowest compressive strength on the one hand and show higher gas permeability coefficients on the other (Fig. 13).

\subsubsection{Leaching process by an ammonium nitrate solution}

Cement-based materials subjected to ammonium nitrate attack underwent dissolution, which led to a leaching process in the following reaction expressed in (1) [45]:

$$
2 \mathrm{NH}_{4} \mathrm{NO}_{3}+\mathrm{Ca}(\mathrm{OH})_{2} \rightarrow \mathrm{Ca}\left(\mathrm{NO}_{3}\right)_{2}+2 \mathrm{NH}_{3}+2 \mathrm{H}_{2} \mathrm{O}
$$


As reported by Schneider and Chen [46], the immediate effect of this attack is total leaching of $\mathrm{Ca}(\mathrm{OH})_{2}$, followed by a progressive decalcification of hydrate products of the hardened concrete. This directly leads to a decrease in weight and strength of the concretes, demonstrated by the results presented in Figs. 16 and 17, which present the mass loss of the concrete mixes immersed in $\mathrm{NH}_{4} \mathrm{NO}_{3}$ at concentrations of $1.5 \mathrm{Mol} / \mathrm{L}$ and $6 \mathrm{Mol} / \mathrm{L}$, and the reduction of tensile splitting strength, respectively. As shown in Fig. 15, after 14 days of immersion, the mass loss of specimens was obvious and its kinetics increased when the $\mathrm{NH}_{4} \mathrm{NO}_{3}$ was used at high concentration $(6 \mathrm{Mol} / \mathrm{L})$, in particular during the first $48 \mathrm{~h}$, except for the concrete mix B4 where the mass loss was consequent. The leaching was similar for other concrete mixes, irrespective of whether it was for concentrations of 1.5 or $6 \mathrm{Mol} / \mathrm{L}$. Therefore, it seems that leaching is related to concrete quality. The concrete mix B4, produced with a full replacement of NAs by RCAs (coarse and fine), presents the poorest quality because of the durability indicators, such as the capillary water absorption, porosity accessible to water, and helium gas permeability, which are the most unfavorable. In addition, the immersion time also played a prominent role (Fig. 17) in the loss of mechanical strength, increased particularly for the B4 concrete. Our results are thus in agreement with those of Schneider and Chen [47], who had observed a reduction in mechanical strength and weight of concrete immersed in $\mathrm{NH}_{4} \mathrm{NO}_{3}$, proportional with the time of immersion.

\section{Fig.16}
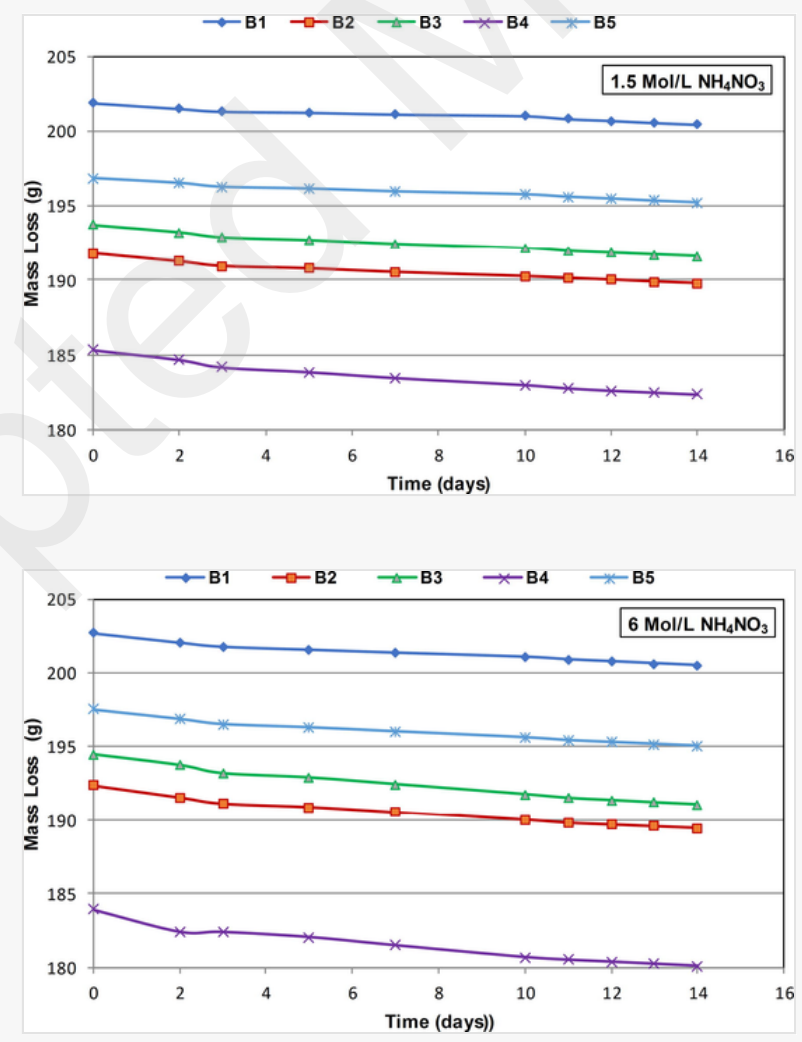

Loss of mass of the specimens immersed in $\mathrm{NH}_{4} \mathrm{NO}_{3}$ Fig. 16a. Concrete mixes immersed in $\mathrm{NH}_{4} \mathrm{NO}_{3}$ at concentration of $1.5 \mathrm{Mol} / \mathrm{L}$ Fig. 16b. Concrete mixes immersed in $\mathrm{NH}_{4} \mathrm{NO}_{3}$ at concentration of $6 \mathrm{Mol} / \mathrm{L}$. 


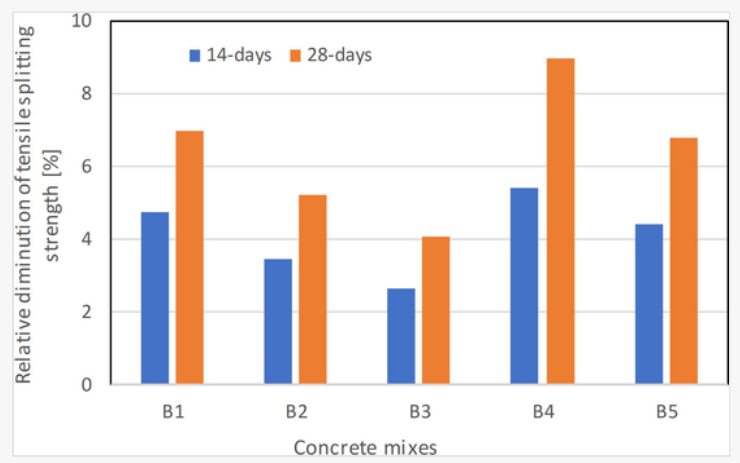

Relative diminution of tensile splitting strength of the concrete mixes after immersion in $\mathrm{NH}_{4} \mathrm{NO}_{3}$ at concentration of $6 \mathrm{Mol} / \mathrm{L}$.

The consequence of decalcification was a neutralization reaction of the specimen which further contributes to reducing the $\mathrm{pH}$ value in the leached part of the specimens. Fig. 18 shows sections of concrete sprayed with phenolphthalein solution after of ammonium nitrate attack $(1.5 \mathrm{Mol} / \mathrm{L})$ on concretes after 14 days' immersion in solution. The pink area of the specimen shows the material sections with a $\mathrm{pH}$ value above 9, which means unaffected. In this figure, it can be seen that the degradation depth on B4 mix is larger than that of B1 mix. Also, an increase of the leaching process time in $\mathrm{NH}_{4} \mathrm{NO}_{3}$ from 14 to 28 days in turn leads to increased penetration depths (Table 5). In this context, Schneider and Chen [46] pointed out that the initial strength of concrete has an impact directly on the degradation of depth. Based on this study, the compressive strength for concrete mixes B2 and B4 based on RCAs records poor performance as compared to other concrete mixes. The affected depth progressed justly for these two concrete mixes when the immersed time passed from 14 to 28 days.

\section{Fig. 18}

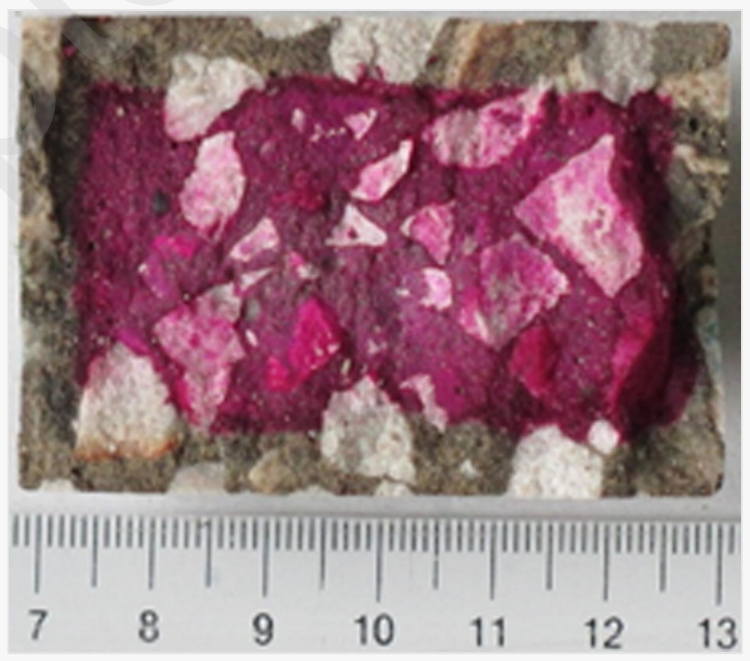




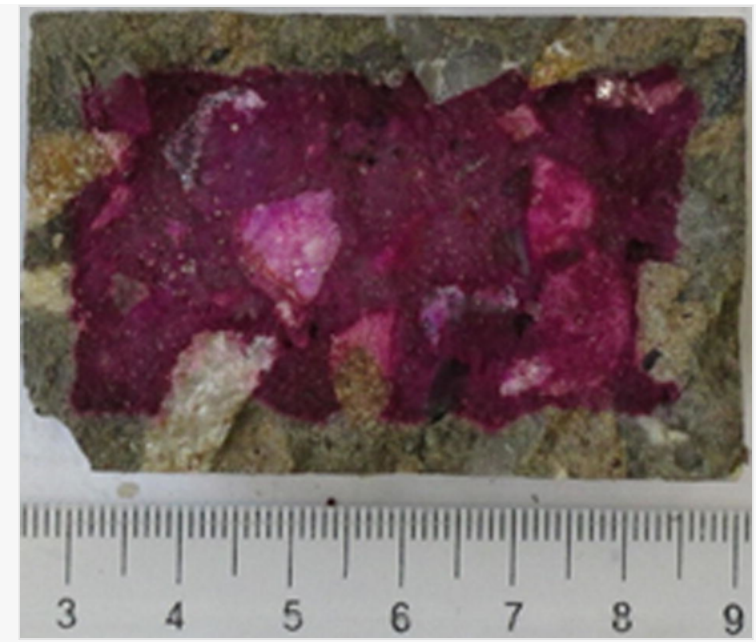

Photographs of a partly leached sections of concrete sprayed with phenolphthalein solution Fig. 18a. B1 mix Fig. $18 \mathrm{~b}$. B4 mix.

Table 5

Degradation depth of specimens immersed in $\mathrm{NH}_{4} \mathrm{NO}_{3}$ at concentration $6 \mathrm{Mol} / \mathrm{L}$.

\begin{tabular}{|l|l|l|}
\hline \multicolumn{2}{|l|}{ Degradation depth (mm) } \\
\hline Concrete mixes & Immersion (days) & \\
\hline & $\mathbf{1 4}$ & $\mathbf{2 8}$ \\
\hline B1 & 5.42 & 10.15 \\
\hline B2 & 5.83 & 10.69 \\
\hline B3 & 5.91 & 10.33 \\
\hline B4 & 6.28 & 11.25 \\
\hline B5 & 5.46 & 9.94 \\
\hline
\end{tabular}

\section{Conclusions}

The results obtained allow us to draw the following main conclusions:

- The replacement of NA by RCAs for producing concrete is possible, even though the workability criteria cannot be well mastered.

- Using RCAs affects mechanical properties of concrete, whether compressive strength or 
splitting tensile strength. Nevertheless, the C25/30 target class of compressive strength is guaranteed.

- RCAs' porous network has influenced physical properties, such as capillary absorption of water and the porosity accessible to water.

- Concretes incorporating RCAs have higher gas permeability coefficients than the reference concrete. The pores contained in the RCA and their interconnections are the result of this deficiency.

- After an ammonium nitrate solution leaching process, the durability properties of concrete containing NA were superior to those of RCA-based concrete. Thus, the kinetics of the leaching process was dependent on the initial resistance of the specimens.

\section{Declaration of Competing Interest}

The authors declare that they have no known competing financial interests or personal relationships that could have appeared to influence the work reported in this paper.

\section{Acknowledgements}

The authors would like to thank to LGCGM laboratory staff of INSA Rennes (France) for providing facilities for conducting various tests in the laboratory.

\section{References}

[1] Pedro D., de Brito J., Evangelista L., Influence of the use of recycled concrete aggregates from different sources on structural concrete, Constr. Build. Mater. 71 (2014) 141-151, doi:10.1016/j.conbuildmat.2014.08.030.

[2] Malešev M., Radonjanin V., Marinković S., Recycled concrete as aggregate for structural concrete production, Sustainability 2 (2010) 1204-1225, doi:10.3390/su2051204.

[3] Mefteh H., Kebaïli O., Oucief H., Berredjem L., Arabi N., Influence of moisture conditioning of recycled aggregates on the properties of fresh and hardened concrete, J. Clean Prod. 54 (2013) 282-288, doi:10.1016/j.jclepro.2013.05.009.

[4] Rodríguez-Robles D., Moran-del Pozo J.M., Garcia-Gonzalez J., Guerra-Romero M.I., JuanValdés A., Effect of mixed recycled aggregates on mechanical properties of recycled concrete, Mag. Concr. Res. 67 (5) (2015) 247-256, doi:10.1680/macr.14.00217. 
Omary S., Ghorbel E., Wardeh G., Nguyen M.C., Mix design and recycled aggregates effects on the concrete's properties, Int. J. Civ. Eng. 16 (8) (2018) 973-992, doi:10.1007/s40999-017-0247$\mathrm{y}$.

[6] Arabi N., Meftah H., Kebaïli O., Berredjem L., Valorization of recycled materials in development of self-compacting concrete: Mixing recycled concrete aggregates - Windshield waste glass aggregates, Constr. Build. Mater. 209 (2019) 364-376, doi:10.1016/j.conbuildmat.2019.03.024.

[7] Bonifazi G., Palmieri R., Serranti S., Evaluation of attached mortar on recycled concrete aggregates by hyperspectral imaging, Constr. Build. Mater. 169 (2018) 835-842, doi:10.1016/j.conbuildmat.2018.03.048.

[8] Arabi N., Berredjem L., Demolition waste recovery as aggregates for concrete, Waste Sci. Technol. 60 (2011) 25-30. http://lodel.irevues.inist.fr/dechets-sciences-techniques/index.php?id= $\underline{2765}$.

[9] Kenai S., Debieb F., Characterization of the durability of recycled concrete based on fine and coarse aggregates of bricks and crushed concrete, Mater. Struct. 44 (2011) 815-824, doi:10.1617/s11527-010-9668-7 [in French].

[10] Etxeberria M., Gonzalez-Corominas A., Properties of Plain Concrete Produced Employing Recycled Aggregates and Sea Water, Int. J. Civ. Eng. 16 (9) (2018) 993-1003, doi:10.1007/s40999-017-0229-0.

[11] Guo H., Shi C., Guan X., Zhu J., Ding Y., Ling T.C., Zhang H., Wang Y., Durability of recycled aggregate concrete - A review, Cement Con. Comp. 89 (2018) 251-259, doi:10.1016/j.cemconcomp.2018.03.008.

[12] Garach L., López M., Agrela F., Ordóñez J., Alegre J., Moya J.A., Improvement of bearing capacity in recycled aggregates suitable for use as unbound road sub-base, Materials 8 (12) (2015) 8804-8816, doi:10.3390/ma8125493.

[13] Martínez I., Etxeberria M., Pavón E., Díaz N., Influence of demolition waste fine particles on the properties of recycled aggregate masonry mortar, Int. J. Civ. Eng. 16 (9) (2018) 1213-1226, doi:10.1007/s40999-017-0280-X.

[14] Silva R.V., de Brito J., Dhir R.K., Fresh-state performance of recycled aggregate concrete: a review, Constr. Build. Mater. 178 (2018) 19-31, doi:10.1016/j.conbuildmat.2018.05.149.

[15] Chen X., Wu S., Zhou J., Influence of porosity on compressive and tensile strength of cement mortar, Constr. Build. Mater. 40 (2013) 869-874, doi:10.1016/j.conbuildmat.2012.11.072.

[16] Li Z., Liu J., Tian Q., Method for controlling the absorbed water content of recycled fine aggregates by centrifugation, Constr. Build. Mater. 160 (2018) 316-325, doi:10.1016/j.conbuildmat.2017.11.068. 
[17] Kebaïli O., Mouret M., Arabi N., Cassagnabere F., Adverse effect of the mass substitution of natural aggregates by air-dried recycled concrete aggregates on the self-compacting ability of concrete: evidence and analysis through an example, J. Clean Prod. 87 (2015) 752-761, doi:10.1016/j.jclepro.2014.10.077.

[18] Quattrone M., Cazacliu B., Angulo S.C., Hamard E., Cothenet A., Measuring the water absorption of recycled aggregates, what is the best practice for concrete production?, Constr. Build. Mater. 123 (2016) 690-703, doi:10.1016/j.conbuildmat.2016.07.019.

[19] Wirquin E., Hadjieva-Zaharieva R., Buyle-Bodin F., Use of water absorption by concrete as a criterion of the durability of concrete - Application to recycled aggregate concrete, Mater. Struct. 33 (2000) 403-408, doi:10.1007/BF02479650.

[20] P.A. Claise Transport Properties of Concrete: Measurement and Applications 2014 Woodhead Publishing is an imprint of Elsevier London, U.K.

[21] J.P. Olivier A. Vichot Durability of concrete 1996 ENPC presses Paris, France [in French].

[22] Thomas C., Setién J., Polanco J.A., Cimentada A.I., Medina C., Influence of curing conditions on recycled aggregate concrete, Constr. Build. Mater. 172 (2018) 618-625, doi:10.1016/j.conbuildmat.2018.04.009.

[23] Corinaldesi V., Moriconi G., Influence of mineral additions on the performance of $100 \%$ recycled aggregate concrete, Constr. Build. Mater. 23 (8) (2009) 2869-2876, doi:10.1016/j.conbuildmat.2009.02.004.

[24] NA 442, Algerian Standard, Cement: Composition, specifications and conformity criteria for common cements 2003 IANOR, Algiers.

[25] EN 12 620, Aggregates for Concrete, European standards, 2002.

[26] G. Dreux, F. Festa, New guide of concrete and its constituents. 8thed. Eyrolles Edition, Paris, France, 2007, [In French].

[27] BS EN 206-1, Concrete: Specification, performance, production and conformity, European standard, 2013.

[28] BS EN 480-5: Admixtures for concrete, mortar and grout - Test methods - Part 5: Determination of capillary absorption, London: British Standards Institution, 2005.

[29] NF EN 18-459, Concrete - Test for hardened concrete - porosity test and density, European standard, 2010.

[30] ASTM C642, Standard test method for density, absorption and voids in hardened concrete, Am. Soc. Test. Mater. (1997). 
[31] Kollek J.J., The determination of the permeability of concrete to oxygen by the cembureau method-A recommendation, Mater. Struct. 22 (1989) 225-230, doi:10.1007/BF02472192.

[32] L. Berredjem, Contribution à l'étude des propriétés des mortiers et bétons à base de granulats recyclés et leurs durabilités. PhD Thesis, Badji Mokhtar-Annaba University, Algeria, 2018, [In French].

[33] Cachim P.B., Mechanical properties of brick aggregate concrete, Constr. Build. Mater. 23 (2009) 1292-1297, doi:10.1016/j.conbuildmat.2008.07.023.

[34] Katz A., Properties of concrete made with recycled aggregate from partially hydrated old concrete, Cem. Con. Res. 33 (2003) 703-711, doi:10.1016/S0008-8846(02)01033-5.

[35] Sérifou M., Sbartaï Z.M., Yotte S., Boffoué M.O., Emeruwa E., Bos F., A study of concrete made with fine and coarse aggregates recycled from fresh concrete waste, J. Constr. Eng. (2013) 5, doi:10.1155/2013/317182.

[36] Poon C.S., Shui Z.H., Lam L., Effect of microstructure of ITZ on compressive strength of concrete prepared with recycled aggregates, Constr. Build. Mater. 18 (2004) 461-468, doi:10.1016/j.conbuildmat.2004.03.005.

[37] Rajhans P., Panda S.K., Nayak S., Sustainable self compacting concrete from C\&D waste by improving the microstructures of concrete ITZ, Constr. Build. Mater. 163 (2018) 557-570, doi:10.1016/j.conbuildmat.2017.12.132.

[38] Xiao J., Li W., Fan Y., Huang X., An overview of study on recycled aggregate concrete in China (1996-2011), Constr. Build. Mater. 31 (2012) 364-383, doi:10.1016/j.conbuildmat.2011.12.074.

[39] J. Weerheijm, Understanding the tensile properties of concrete, Woodhead Publishing Limited, Oxford Cambridge Philadelphia New Delhi, 2013.

[40] Djerbi A., Effect of recycled coarse aggregate on the new interfacial transition zone concrete, Constr. Build. Mater. 190 (2018) 1023-1033, doi:10.1016/j.conbuildmat.2018.09.180.

[41] Poon C.S., Shui Z.H., Lam L., Fok H., Kou S.C., Influence of moisture states of natural and recycled aggregates on the slump and compressive strength of concrete, Cement Con. Res. 34 (2004) 31-36, doi:10.1016/S0008-8846(03)00186-8.

[42] M. Barra de Oliveira, E. Vazquez, Properties of concretes with recycled aggregates: influence of properties of the aggregates and their interpretation. Proceeding of the International Symposium on Sustainable Construction: Use of Recycled Concrete Aggregate, London UK, (1998) 19-30. $\underline{\mathrm{h}}$ ttps://www.icevirtuallibrary.com/doi/pdf/10.1680/scuorca.27268.0002.

[43] Vieira T., Alves A., de Brito J., Correia J.R., Silva R.V., Durability-related performance of concrete containing fine recycled aggregates from crushed bricks and sanitary ware, Mater. Des. 90 (2016) 767-776, doi:10.1016/j.matdes.2015.11.023. 
[44] Xuan D., Zhan B., Poon C.S., Durability of recycled aggregate concrete prepared with carbonated recycled concrete aggregates, Cement Con. Comp. 84 (2017) 214-221, doi:10.1016/j.cemconcomp.2017.09.015.

[45] Wong L.L., Asrah H., Rahman M.E., Mannan M.A., Effects of aggressive ammonium nitrate on durability properties of concrete using sandstone and granite aggregates, Int. J. Civ. Env. Eng. 7 (1) (2013) 49-53, doi:10.5281/zenodo.1063130.

[46] U. Schneider, S.W. Chen, The leaching effect of concrete immersed in ammonium nitrate solution. RILEM TC 211-PAE Final Conference: Concrete in Aggressive Aqueous Environments: Performance, Texting and Modelling, Toulouse, France, 3-5 June 2009, 54-64. ht tps://www.rilem.net/publication/publication/67?id_papier=2514.

[47] Schneider U., Chen S.W., Behavior of high-performance concrete (HPC) under ammonium nitrate solution and sustained load, ACI Mater. J. 96 (1) (1999) 47-51, doi:10.14359/427.

\section{Highlights}

- Mechanical strength and some durability indicators were tested.

- The use of recycled aggregates affects the compressive strength of concrete.

- Replacing NA by RCA compromises the durability properties of concrete.

- The kinetics of the leaching process by $\mathrm{NH}_{4} \mathrm{NO}_{3}$ depended on the initial strength of the concrete. 